\title{
HUBUNGAN KUALITAS PELAYANAN LARISSA AESTHETIC CENTER SEMARANG DAN MANFAAT KEPEMILIKAN MEMBER CARD PRIVILEGE TERHADAP LOYALITAS PELANGGAN
}

\author{
Ovika Khurrota A'yun
}

\begin{abstract}
Larissa Aesthtetic Center is one of the beauty and skin care clinics in Semarang City. They perform a variety of ways loyalty program that is wrong through the membercard. As performed by Larissa Aesthetic Center Semarang who issued Privilege membercard where many benefits that can be obtained by consumers. This research is intended to know the service quality of Larissa Aesthtetic Center Semarang to customer loyalty and also to know the relation of member privilege to customer loyalty. The theory used to support this research is Servqual theory. This research is type of explanatory research with sample of 100 customer of Larissa Semarang taken by purposive sampling technique. While the data analysis is done by Kendall Tau-b wake test.

The result of hypothesis test shows that there is a correlation between service quality of Larissa Aesthetic Center Semarang with Customer Loyalty with significance value equal to $0,000<0.05$ and the result value of 0.379 indicates a weak relationship with customer loyalty. Thus, the hypothesis that the relationship between service quality and customer loyalty is accepted. Furthermore, the benefits of membercard privillege have a significance value of $0.000<0.05$ and a value of 0.303 indicating a weak relationship with customer loyalty. Thus, the hypothesis stating the relationship between the benefits of membercard and customer loyalty is accepted. The suggestion given is that Larissa can improve the service quality so that it is expected to build or increase customer loyalty.
\end{abstract}

Keywords: Quality of Service, Member Card, Customer Loyalty

\section{PENDAHULUAN}

Penelitian ini menggunakan uji korelasi Kendall Tau-b dibantu dengan program SPSS 16. Uji korelasi Kendall Tau-b merupakan uji statistik non parametrik yang tidak mensyaratkan data harus berdistribusi normal. Uji Kendall Tau$\mathrm{b}$ dilakukan untuk menguji hubungan antara dua variabel atau lebih yang berdata ordinal. Pada uji korelasi dilihat dari tingkat signifikansi, jika ada maka akan dicari seberapa kuat hubungan tersebut. Keeratan hubungan ini dinyatakan dalaam bentuk koefisien korelasi (Sujarweni,
2014:127). Tingkat signifikan digunakan untuk menyatakan apakah dua variabel mempunya hubungan dengan syarat: - $\quad$ Sig $>0,05 \mathrm{Ho}$ diterima artinya tidak terdapat

$$
\text { hubungan - Sig }<0,05 \text { Ho ditolak }
$$
artinya terdapat

hubungan

Sifat korelasi akan menentukan arah dan korelasi. Keeratan korelasi dapat dikelompokkan sebagai berikut: (Sujarweni,2014:17)

- 0.00 sampai 0.20 bearti korelasi memiliki 
- 0.21 sampai 0.40 bearti korelasi memiliki keeratan lemah

- 0.41 sampai 0.70 bearti korelasi memiliki keeratan kuat

- 0.71 sampai 0.99 bearti korelasi memiliki keeratan sangat kuat

- 1 bearti korelasi sempurna

Penelitian ini melakukan uji korelasi antara kualitas pelayanan (X1) dengan loyalitas pelanggan Larissa Aesthetic Center (Y), dan korelasi antara manfaat membercard (X2) dengan loyalitas pelanggan Larissa Aesthetic Center.

\subsubsection{Hubungan Antara Kualitas Pelayanan (X1) dengan Loyalitas Pelanggan (Y)}

Uji korelasi Kendall Tau-b dgunakan untuk menguji ada atau tidaknya hubungan antara kualitas pelayanan (X1) dengan loyalitas pelanggan $(\mathrm{Y})$.
0.379 yang bearti angka tersebut menunjukkan adanya hubungan yang lemah antara kualitas pelayanan (X1) dengan loyalitas pelanggan Larissa Aesthetic Center (Y). Dengan demikian, Hipotesis 1 yang menyatakan bahwa terdapat hubungan antara kualitas pelayanan(X1) dengan loyalitas pelanggan Larissa Aesthetic Center(Y) diterima

\subsubsection{Hubungan Antara Manfaat Membercard (X2) dengan Loyalitas Pelanggan (Y)}

Uji korelasi Kendall Tau-b dgunakan untuk menguji ada atau tidaknya hubungan antara kualitas pelayanan (X1) dengan loyalitas pelanggan (Y).

Tabel 3.3 di atas menunjukkan nilai signifikansi dari variabel manfaat membercard (X2) dengan loyalitas pelanggan (Y) sebesar 0.000 dimana $0.000<0.05$, maka terdapat hubungan antara manfaat membercard dengan

Tabel 4. 1

Uji Korelasi Kendall Tau-b antara Kualitas pelayanan dengan Loyalitas Pelanggan.

Correlations

\begin{tabular}{|c|c|c|c|c|}
\hline & & & $\begin{array}{c}\text { Mualitas } \\
\text { Pelayanan }\end{array}$ & $\begin{array}{l}\text { I nyalitas } \\
\text { PElanggan }\end{array}$ \\
\hline \multirow[t]{6}{*}{ Kendall's tau_b } & Kualitas Fylayanar & Corelation coefficient & 1.000 & $37 c^{\prime \prime}$ \\
\hline & & Sid. (2-tailed) & & $\Pi$ \\
\hline & & $\mathrm{N}$ & 100 & $1[0$ \\
\hline & Loyalitas Pelanggan & Corelation coefficient & $379^{\prime \prime}$ & 1.000 \\
\hline & & Big. (2-tailed) & .000 & \\
\hline & & $\mathrm{N}$ & 100 & $1[0$ \\
\hline
\end{tabular}

\#. Correlation is significant at the 0.01 level (2-tailed).

Tabel 3.2 menunjukkan nilai signifikansi dari variabel kualitas pelayanan (X1) dengan loyalitas pelanggan (Y) sebesar 0.000 dimana $0.000<0.05$, maka terdapat hubungan antara kualitas pelayanan dengan loyalitas pelanggan Larissa Aesthetic Center. Selanjutnya dapat diketahui bahwa nilai koefisien korelasi sebesar loyalitas pelanggan Larissa Aesthetic Center. Selanjutnya dapat diketahui bahwa nilai koefisien korelasi sebesar 0.303 yang bearti angka tersebut menunjukkan adanya hubungan yang lemah antara manfaat membercard (X1) dengan loyalitas pelanggan Larissa Aesthetic Center (Y). Dengan demikian, Hipotesis II yang menyatakan 
Tabel 4.2

Uji Korelasi Kendall Tau-b antara Kualitas pelayanan dengan Loyalitas Pelanggan.

Correlations

\begin{tabular}{|c|c|c|c|c|}
\hline & & & $\begin{array}{c}\text { Manfaat } \\
\text { Membercard }\end{array}$ & $\begin{array}{l}\text { Loyalitas } \\
\text { Pelanggan } \\
\end{array}$ \\
\hline \multirow[t]{6}{*}{ Kendall'stau_b } & \multirow[t]{3}{*}{ Wanfaat Wembercard } & Correlation Coeficient & 1.000 & $303^{\prime \prime}$ \\
\hline & & Sig. (2-tailed) & & .000 \\
\hline & & $\mathrm{N}$ & 100 & 100 \\
\hline & \multirow[t]{3}{*}{ Loyalitas Pelanggan } & Correlation Coefficient & $.303^{\prime \prime}$ & 1.000 \\
\hline & & Sig. (2-tailed) & .000 & \\
\hline & & $\mathrm{N}$ & 100 & 100 \\
\hline
\end{tabular}

* Correlation is significant at the 0.01 level (2-tailed).

bahwa terdapat hubungan antara manfaat membercard (X2) dengan loyalitas pelanggan Larissa Aesthetic Center (Y) diterima.

\subsection{Pembahasan}

Penelitian ini bertujuan untuk mengetahui hubungan kualitas pelayanan dan manfaat kepemilikan membercard dengan loyalitas pelanggan Larissa Aesthetic Center Semarang.

\subsubsection{Hubungan Kualitas Pelayanan dengan Loyalitas Pelanggan Larissa Aesthtetic Center Semarang}

Hasil uji korelasi menunjukkan bahwa variabel kualitas pelayanan (X1) memiliki hubungan dengan loyalitas pelanggan (Y), meskipun sifatnya sangat lemah. Hal ini sesuai dengan teori SERVQUAL yang menyatakan bahwa Kualitas memiliki hubungan yang erat dengan kepuasan pelanggan. Kualitas memberikan suatu dorongan kepada pelanggan untuk menjalin ikatan hubungan yang kuat dengan perusahaan. Dalam jangka panjang ikatan seperti ini memungkinkan perusahaan untuk memahami dengan seksama harapan pelanggan serta kebutuhan mereka.
Dengan demikian, perusahaan dapat meningkatkan kepuasan pelanggan di mana perusahaan memaksimumkan pengalamanpelanggan yang menyenangkan dan meminimumkan pengalaman-pelanggan yang kurang menyenangkan. Ketika pelanggan menerima kualitas pelayanan yang lebih baik dari uang yang dikeluarkannya, mereka percaya menerima nilai yang baik (good value), dimana hal ini akan meningkatkan loyalitasnya. Konsumen juga seringkali dapat menarik kesimpulan mengenai kualitas pelayanan berdasarkan penilaian mereka terhadap tempat atau lokasi, orang, peralatan, alat komunikasi dan harga yang mereka lihat sebelum mereka memutuskan untukmelakukan pembelian kembali dimasa mendatang (Kotler, 2009).

Adanya hubungan antara variabel kualitas pelayanan dengan loyalitas pelanggan menunjukkan bahwa teori SERVQUAL terbukti dilapangan, meskipun hubungan antara kedua variabel tersebut bersifat lemah. Dalam teori ini dijelaskan bahwa memaksimumkan pengalamanpelanggan yang menyenangkan dan meminimumkan pengalaman-pelanggan yang kurang menyenangkan. Hal ini bearti bahwa semakin tinggi kualitas pelayanan maka semakin tinggi pula loyalitas pelanggan di perusahan tersebut. Begitu pun sebaliknya semakin rendah tingkat kualitas 
pelayanan maka semakin rendah pula loyalitas pelanggan suatu perusahaan.

\subsubsection{Hubungan Manfaat Member Card Privillege dengan Loyalitas Pelanggan Larissa Aesthtetic Center Semarang}

Hasil uji korelasi menunjukkan bahwa variabel manfaat membercard privillege (X2) memiliki hubungan dengan loyalitas pelanggan (Y), meskipun sifatnya sangat lemah. Hal ini sesuai Dengan adanya membership card, pihak perusahaan dapat menghitung banyaknya pelanggan yang ada serta implikasinya terhadap perusahaan. Dengan demikian dapat dilakukan evaluasi dalam perusahaan, apakah penggunaan membership card berguna baik bagi perusahaan ataupun pengguna membership card (Gronroos, 2000).

Perusahaan dapat membuat program frekuensi yang dirancang untuk para pelanggan. Program frekuensi dirancang untuk memberikan penghargaan yang sering membeli dalam jumlah besar. Program ini dapat membantu membangun loyalitas jangka penjang dengan memberi nilai seumur hidup pelanggan tertinggi. Hal ini didasarkan pada beberapa penelitian yang dilakukan diantaranya: Bolton, Kannan \& Bramlet dalam Lupiyoadi (2008:197) menemukan bahwa pelanggan yang menjadi anggota program cendrung memiliki ikatan emosional yang lebih kuat dari pada mereka yang non anggota, kurang memperhatikan kinerja perusahaan pesaing, anggota program sedikit kurang sensitif pada kerugian yang diakibatkan oleh faktor finansial. Wijaya (2007:10) menyatakan manfaat yang diterima pelanggan dengan memiliki membership card adalah memproleh manfaat finansial berupa diskon atau potongan harga, bonus produk atau hadiah berdasarkan pengumpulan poin, mendapat pelayanan yang lebih baik.
Adanya hubungan antara variabel manfaat membercard dengan loyalitas pelanggan menunjukkan bahwa apa yang diungkapkan Gronroos tentang manfaat membercard terhadap loyalitas pelanggan terbukti dilapangan, meskipun hubungan antara kedua variabel tersebut bersifat lemah. Dalam teori ini dijelaskan bahwa perusahaan dapat memberikan suatu reward atau harga khusus untuk membangun hubungan yang baik dengan pelanggan. Hal ini bearti bahwa semakin tinggi manfaat membercard yang diberikan perusahaan maka semakin tinggi pula loyalitas pelanggan di perusahan tersebut. Begitu pun sebaliknya semakin rendah manfaat membercard yang diberikan maka semakin rendah pula loyalitas pelanggan suatu perusahaan.

\subsection{KESIMPULAN}

1. Berdasarkan Hasil Uji Statistik Kendall Tau$\mathrm{b}$, variabel kualitas pelayanan memiliki nilai signifikansi $0.000<0.05$ dan nilai koefisien korelasi sebesar 0.379 sehingga menunjukkan adanya hubungan yang lemah dengan loyalitas pelanggan. Maka, hipotesis yang menyatakan bahwa terdapat hubungan antara kualitas pelayanan dengan loyalitas pelanggan diterima.

2. Berdasarkan Hasil Uji Statistik Kendall Tau-b, variabel manfaat membercard privillege memiliki nilai signifikansi $0.000<$ 0.05 dan nilai koefisien korelasi sebesar 0.303 sehingga menunjukkan adanya hubungan yang lemah dengan loyalitas pelanggan. Maka, hipotesis yang menyatakan bahwa terdapat hubungan antara manfaat membercard dengan loyalitas pelanggan diterima. 


\subsection{SARAN}

1. Penelitian ini menunjukkan adanya hubungan yang lemah antara kualitas pelayanan dengan loyalitas pelanggan Larissa Aaesthetic Center Semarang. Dari hasil penelitian tersebut Larissa Aesthetic Center sebagai perusahaan yang bergerak dibidang jasa dan produk perawatan kecantikan dapat meningkatkan kualitas pelayanannya seperti pada waktu tunggu yang singkat, informasi yang lebih mudah dipahami mengingat segmen yang berbeda latar belakang sehingga diharapkan dapat membangun atau meningkatkan loyalitas pelanggan terhadap Larissa Aesthetic Center Semarang.
2. Penelitian ini menunjukkan adanya hubungan yang lemah antara manfaat membercard dengan loyalitas pelanggan Larissa Aaesthetic Center Semarang. Dari hasil penelitian tersebut dapat diketahui kedepannya Larissa Aesthetic Center sebagai perusahaan yang bergerak dibidang jasa dan produk perawatan kecantikan dapat membuat perbaikan dalam program membership cardseperti memberikan potongan harga yang kontinui, memberikan reward kepada member dengan ketentuan yang diterapkan, memberikan kemudahan akses perawatan kepada member agar kegiatan program manfaat kepemilikan membercard berpengaruh positif dan signifikan sehinggadapat meningkatkan loyalitas pelanggan terhadap Larissa Aesthetic Center Semarang. 